THE JOURNAL OF PHILOSOPHICAL ECONOMICS:

REFLECTIONS ON ECONOMIC AND SOCIAL ISSUES

Volume XIV Issues 1-2

Spring-Autumn 2021

ISSN: $1843-2298$

EISSN: $1844-8208$

Publication date:

20 November 2021

Paper format: $16.5 \times 23.5 \mathrm{~cm}$

Copyright note:

Authors retain unrestricted copyright and all publishing rights in compliance with the Creative Commons license CC BY-NC-SA.
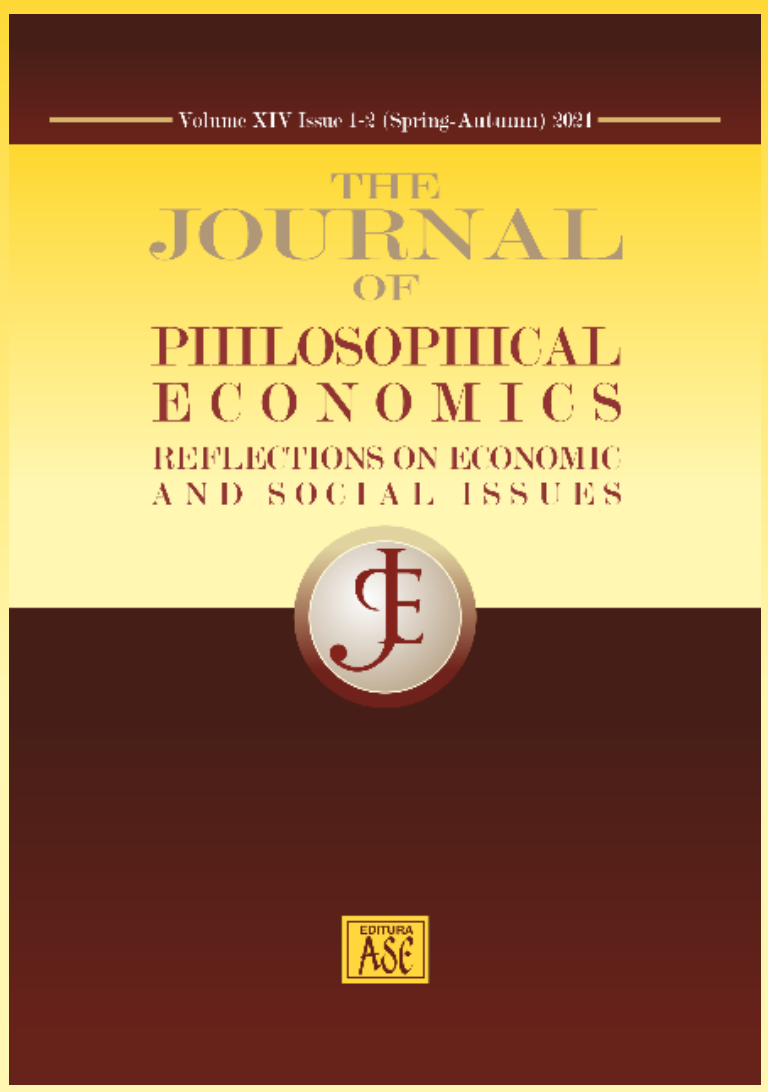

\title{
Justice and just price in Francisco de Vitoria's Commentary on Summa Theologica II-II q77
}

José Luis Cendejas Bueno 


\title{
Justice and just price in Francisco de Vitoria's Commentary on Summa Theologica II-II q77
}

\author{
José Luis Cendejas Bueno
}

\begin{abstract}
Following Thomas Aquinas, Francisco de Vitoria's analysis of justice in exchanges takes place by commenting on the corresponding questions of the Summa Theologica. The identification of the just price with that of common estimation occurs under a sufficient concurrence of sellers and buyers. A high level of concurrence limits the ability to take advantage of the need on the other side of the market. This fact guaranties a full consent of the parties involved in trading. Under conditions of market power or when some authority fixes a legal price, just price should also be taken as a normative ideal.
\end{abstract}

Keywords: Francisco de Vitoria, just price theory, Scholastic economic thought, School of Salamanca

\section{Introduction: Francisco de Vitoria and the School of Salamanca}

Although other authors of the School of Salamanca have been given more attention from the perspective of economic thought, it is Francisco de Vitoria (Burgos, 1483 - Salamanca, 1546) who is recognized as the teacher and founder of this School (Belda 2000, 157; Barrientos 2005, 2011; Pena 2009, 52-53). Vitoria renewed theological teaching in the University of Salamanca after establishing Thomas Aquinas' Summa Theologica (STh) as the reference textbook rather than Peter Lombard's Libri Quattuor Sententiarum (ca. 1150), the former having a sound foundation on Canonical and Roman law in addition to its Aristotelian inspiration. Vitoria based his regular classroom lessons on the commentary on the Summa, while the Relectiones [1] (conferences) were lectures reserved for the main holidays of the year in accordance with the customs of the University. Vitoria is specially recognized due to his contributions to human rights and international law. Clarifying what was due, in law, to the Indians was a scientific

Received: 14 May 2021

The Journal of Philosophical Economics XIV (1-2) 2021 
Cendejas Bueno José Luis (2021), Justice and just price in Francisco

de Vitoria's Commentary on Summa Theologica II-II q77,

The Journal of Philosophical Economics: Reflections on Economic and Social Issues,

XIV (1-2), 1-32

challenge of the highest order. Vitoria provided a response to this question by laying the foundations of what today is called international law [2], which, then, was based on the law of nations (ius gentium) [3]. In this sense, Vitoria had a meaningful influence on Hugo Grotius [4].

Regarding law and justice, which incorporate economic thought, we have Vitoria's comments on parts I-II of the Summa (Prima Secundae, questions 90 to 108, or treatise De Legibus) and parts II-II (Secunda Secundae, in which the treatise De Iustitia et Iure is found, questions 57 to 79). These commentaries were preserved thanks to the students' notes, as they were not published during Vitoria's lifetime, hence the importance of the editorial and translation work based on these manuscripts such as that completed by Beltrán de Heredia among others [5]. From the point of view of economic thought, the name of the School of Salamanca (understood in a broader sense than the nucleus of Dominican theologians at the University) is found in Chapter III of the reception address by José Larraz (1943) as a fellow of the Spanish Academia of Ciencias Morales y Políticas, entitled El cuantitativismo monetario de Salamanca [6]. Professor Viñas y Mey drew Marjorie Grice-Hutchinson's attention to this work (GriceHutchinson, 1989). She was responsible for telling Hayek, her doctoral thesis director, about the existence and importance of this School (Gómez Rivas, 2002). Grice-Hutchinson's book, The School of Salamanca: Readings in Spanish Monetary Theory, 1544-1605, published in 1952, began the most recent interest in the Spanish Scholastics of the 16th century in the field of economic thought. This work describes how these doctors and other authors [7], who did not form part of the School of Salamanca in a more restrictive sense, developed a theory of price and money based on subjective valuation [8], analysed the formation of competitive pricing, and established the fundamentals of the quantity theory of money in the attempt to explain the inflationary process affecting Spain and the rest of Europe (see Hamilton 1934; Munro 2008; Cendejas and Font 2015).

Concerning the theory of value, of the two theories under discussion, the one based on common estimation and the one based on embodied costs which was already disproved by Saravia de la Calle (Grice-Hutchinson 1952, 48), it was the second which prevailed during much of the $19^{\text {th }}$ century developed by the Classical Economics, until finally the Marginalist Revolution, around 1870, re-established 
Cendejas Bueno, José Luis (2021), Justice and just price in Francisco

de Vitoria's Commentary on Summa Theologica II-II q77,

The Journal of Philosophical Economics: Reflections on Economic and Social Issues,

XIV (1-2), 1-32

the subjective focus after 'a time- and labour-consuming detour' (Schumpeter 1954, 97). Concerning money, Azpilcueta's formulation of the quantity theory is based on the fact that money is a special type of merchandise and, as such, its worth can change. Azpilcueta thus formulates the quantity theory of money in 1556, twelve years before than Bodin and in a clearer manner than Copernicus [9]. He also developed the theory of purchasing power parity to explain exchange rates, anticipating both Cassel, as Larraz points out, and Gerard de Malynes, to whom Schumpeter attributes the theory's inception in 1601.

Other terms used for the School of Salamanca in the history of economic thought have been Hispanic Scholasticism (Chafuen 2003), Indian Scholasticism [10] (Popescu 1997) because of the American developments about the quantity theory in the surroundings of the Audiencia de Charcas in which were the silver mines of Potosí, and Late Spanish Scholastics (Rothbard 1995). Presently, the recognition of the contribution of the Spanish Scholastics to economic thought is reflected in several textbooks [11].

Because of Francisco de Vitoria's position as founding father of the School of Salamanca, and the importance of this school on economic thought, this work deals with Vitoria's analysis of justice in exchanges, and the theory of the just price as a paradigmatic example of the approach that other members of the School would later follow [12]. The reflection on law and justice in general, and the realization of fairness in exchanges in particular, occurs when commenting on questions 57, 58 and 61 of the Secunda Secundae of the Summa Theologica concerning law, justice and its parts (edited by Frayle 2001), and on question 77 on buying and selling (in Francisco de Vitoria 2006). In this article we analyse the contents of these lessons, placing Vitoria's contributions in the context both of the Scholastic tradition, especially Thomas Aquinas, and of the School of Salamanca.

The structure of this work replicates the logic of the argument that supports the concept of just price. In section 2 we present the concept of justice that underlies Scholastic thinking, and that Francisco de Vitoria assumes. Justice is understood as a virtue which concerns personal action, and manifests itself in three dimensions (political, distributive, and commutative) according to the social nature of man. With its roots both in Aristotelian thought and in the 
Cendejas Bueno José Luis (2021), Justice and just price in Francisco

de Vitoria's Commentary on Summa Theologica II-II q77,

The Journal of Philosophical Economics: Reflections on Economic and Social Issues,

XIV (1-2), 1-32

Roman law, justice is understood as 'give each one his own'. It is in this framework that the concept of 'just price' makes sense. Section 3 addresses the way in which the exchange of things of identical value is achieved through common estimation, the theory of value that this solution implies, and the conditions of concurrence of bidders and claimants that make it possible. When common estimation is absent, it is necessary to follow other rules whose ultimate goal is that the exchanges are fully voluntary for both sides of the market. Whether there is high concurrence or not, buying and selling decisions, as acts in which personal responsibility is assumed, must be intentionally fair. In general, justice can result both from personal action and from law, this being a sort of reason for or cause of the right. In this regard, in section 4, we address the issue of the legal price. For Vitoria, the legal price is just if it is within the range of what would be the price of common estimation or if takes into consideration some substitutes (embodied costs, arbitrium boni viri) previously considered, which avoids the arbitrariness of the authorities.

\section{Justice and dealings between equals}

For Scholastic thought, consistent with the Aristotelian-Thomistic approach, justice is the virtue on which the realization of good within the political community depends. Justice generates a social order that does not come from violence or coercion. In the field of exchanges in the market, justice requires free acts for which a mere consent by both parties is not enough. Rather, there must be real conditions that allow for the possibility of a fully voluntary act, which in turn depends on what we could call symmetry of needs in the acts of purchase and sale. As a result of this symmetry, buyer and seller proceed to exchange equivalent things (that is, by paying a just price) so that buyer and seller mutually benefit to the same extent and thus comply with a principle of commutative justice. This is the fundamental requirement of a lawful (licit) purchase. Langholm (1998a) speaks of absence of compulsion to refer to the fact that, in a transaction, one of the agents does not take advantage of the other's need. If this were not the case, the act would not be fully voluntary for the agent who benefits to a lesser extent. Rather, it would be called 'mixed voluntary' according to the Aristotelian typology (Nic Eth III, 1). The concept of just price 
Cendejas Bueno, José Luis (2021), Justice and just price in Francisco

de Vitoria's Commentary on Summa Theologica II-II q77,

The Journal of Philosophical Economics: Reflections on Economic and Social Issues,

XIV (1-2), 1-32

rests on a principle of justice that, as we will see below, has a double meaning, both legal (positive law) and moral (natural law).

For Francisco de Vitoria, justice differs from other virtues in that it consists of a relationship with respect to another and not to oneself as happens, for example, with temperance or fortitude (Vitoria's commentary on STh II-II, q57, a1; q58, a1). What is just is equal, and what is equal is always in relation to another [13]. As a virtue, it must be done consciously and by free decision, with assertiveness and for its own purpose (commentary on STh II-II, q58, a1). Thomas Aquinas' definition of justice ('a habit whereby a man renders to each one his due by a constant and perpetual will', STh II-II, q58, a1) is ideal, universal, and includes these three terms: living honestly, not harming anyone and giving each man what he deserves [14]. If a man gives others what they deserve, he lives honestly and commits no injustice to anyone. Justice extends to 'achieve equality in accordance with another', although the law is also with respect to oneself. Paying a penalty is part of 'giving everyone what they are due', whether that is to the injured person, to the community or to the one who committed the injustice, Vitoria states.

Justice deals with what is owed, and what is owed seeks to preserve an equality that dispenses with the condition of the agents (commentary on STh II-II, q57, a1). For example, it does not matter whether the buyer is rich or poor, as long as he gives the equivalent. Strictly speaking, the right (ius) is the just thing and justness is the object of justice (iustitia): as a consequence of there being justice, something just is achieved. The just thing is not legislation (lex). The latter is rather a rule to adjust to, a sort of reason for or cause of the right. When jurists state that justice is 'a firm and constant will to give each one his right', it is clear that the right is not treated as equal to legislation.

Vitoria states that not any virtue is sufficient to guide the works towards a positive outcome and the common good, although this may happen accidentally, but that justice or charity are the virtues that direct the acts toward the common good or toward God respectively (commentary on STh II-II, q58, a6). A special virtue is needed for the preservation of the public good and this is justice, because it is difficult to do well in relation to compliance with the regulations. Justice is the most perfect virtue among the moral virtues as it is directed to the 
Cendejas Bueno José Luis (2021), Justice and just price in Francisco

de Vitoria's Commentary on Summa Theologica II-II q77,

The Journal of Philosophical Economics: Reflections on Economic and Social Issues,

XIV (1-2), 1-32

governance and conservation of the kingdom and includes 'very perfect acts', such as preventing war or sedition and achieving equality (commentary on STh II-II, q58, a12).

Scholastic thought accepts the division of the justice that Aristotle proposes, considering that the right (ius) in exchanges falls within the scope of commutative justice. Aristotle divides justice into particular and general. General justice refers to the relation of the members of the polis to the polis itself and is also called political justice. This is only possible between free and equal people (Nic Eth V, 1134a25-30), so it differs from domestic justice [15]. The latter is what Francisco de Vitoria accepts (commentary on STh II-II, q57, a4). For Aquinas and Vitoria, the right, justness in absolute terms, is what applies in relation to another that is equal, for example between two men in which neither is subjected to the other, but both to the same prince (also in Nic Eth V, 1134b: to speak of injustice, one has to pay attention to the laws established by the prince).

Particular justice, in turn, is divided into distributive and corrective (or commutative) justice. Distributive justice refers to what the polis owes its members proportionately as they contribute in a different way to the good of the polis. For example, different contributions will lead to unequal recognition of merits or honours. The various dealings between men, whether voluntary (purchase, sale, loan, bail, usufruct, deposit, or rent) or involuntary (basically crimes that require punishment or reparation to restore the equality prevailing prior to their commission), must be carried out while preserving equality among citizens. Vitoria states that justice is commutative if it establishes order between two private persons, for example, if it makes buyers and sellers equal (commentary on STh II-II, q61, a1). It is distributive justice if it establishes order between the republic or community and a private person. Coinciding with Cajetan [16], there are three species of justice: legal, which orients the parts to the whole (as the citizen with the king), commutative, which orients the parts one to another, and distributive, which orients the whole to the parts. Although what is owed belongs both to the commutative and the distributive justice, greater debt is in the commutative, so that if something deviates from commutative justice, it becomes greater injustice. Following Aristotle, Vitoria states that the point of equilibrium in commutative justice is determined by the 
Cendejas Bueno, José Luis (2021), Justice and just price in Francisco

de Vitoria's Commentary on Summa Theologica II-II q77,

The Journal of Philosophical Economics: Reflections on Economic and Social Issues,

XIV (1-2), 1-32

arithmetical proportion keeping the proportion of the thing to the thing, while in the distributive, equilibrium is determined by the proportion of the thing to the person (commentary on STh II-II, q61, a2).

A special type of relationship between members of the polis is reciprocity. The reciprocally proportionate actions keep the polis united. Exchanges mediated by money belong to reciprocity. Money allows the equalization of the unequal through necessity. By acting as a substitute for necessity, money, a conventional measure established by virtue of an agreement, solves the problem of the commensurability necessary for such equalization, at least to a sufficient degree [17] (Nic Eth V, 1133a15-30). Following this approach, Vitoria asks if justness is the same as contrapassum, that is, the law of the Talion, or reciprocity. In the exchange, it seems to occur because what is received is valued as much as what is given. For that reason, exchange belongs to commutative justice (commentary on STh II-II, q61, a4).

Vitoria, continuing with the commentary to Thomas Aquinas, and in relation to buying and selling (STh II-II, q77), considers the circumstances that could make a purchase fraudulent and, consequently, as theft or robbery [18]. Corresponding to the articles of q. 77, four aspects are addressed: (i) the unfair sale because of the price (which relates to the theory of the just price); (ii) the injustice because of a defect in relation to the thing sold; (iii) the obligation to declare the defects of the thing sold; and (iv), the increase in price when selling with respect to the cost of acquisition (which could be understood as a theory of profit). According to Schumpeter [19], the fact that q. 77 deals with fraud reveals that Thomas Aquinas understands the just price as the price of a normal competitive market, although he does not explicitly clarify this, as this was something assumed by jurists. If the market is competitive, sellers can hardly impose a price higher than the market price: what they can then do is cheat with quality or quantity, which is what this question is about [20]. Indeed, both for Aquinas and for Vitoria, an unfair sale is the result of fraud, deception, or an asymmetry of needs. The latter results, although not always, from the existence of market power in the form of monopoly or monopsony [21]. 
Cendejas Bueno José Luis (2021), Justice and just price in Francisco

de Vitoria's Commentary on Summa Theologica II-II q77,

The Journal of Philosophical Economics: Reflections on Economic and Social Issues,

XIV (1-2), 1-32

\section{Just price, common estimation, and profit}

The presence of involuntariness in exchanges due to ignorance or violence would liken the sale to theft or robbery, hence its condemnation [22]. Some violence is exerted on the needy when the monopolist or the monopsonist takes advantage of their need by obtaining an illicit profit through an unjust price. Even if, under these conditions, buying or selling is accepted, the act becomes 'mixed voluntary' (Nic Eth III, 1). On the contrary, the exchange is fair if the price equals the value of the thing with what is actually paid for it. This value results from a common estimation [23] that comes from a sufficient concurrence of buyers and sellers who, interacting freely, express a shared opinion about the value of the thing. The exchange at a just price preserves the equality of the thing with the payment for it, so that neither buyer nor seller suffer an injustice. Only in the absence of a common estimation should the various circumstances be attended to that, on production-side, allow for achieving the act of sale (expenses, labour, risk, or scarcity), that is, it is necessary to consider the production costs. So, with the price determined in this way, we find a just price that replaces the price of common estimation. It is important to note that it is a legal and ethical solution which does not presume a theory of value based on costs [24].

Beginning with Thomas Aquinas' analysis of the question of the legality of selling something more expensive than it is worth (STh II-II, q77, a1), the answer is clear: selling above the just price is a sin when deceiving the neighbour, to his disadvantage. It is also sinful that the seller puts a bidder that raises the price, or the buyer another that reduces it (Aquinas cites here Cicero in De Officiis III, 61 . That is, any kind of fraud that alters the price is unlawful. Excluding fraud and in its essence, the sale seems established in the interest of both parties by mutual need. Therefore, it should not be to the detriment of one of the parties: the contract should be based on the equality of the thing [25]. The value is set in monetary terms, hence the need to pay attention to whether the price exceeds or does not cover the value of the thing, which would be unfair. Fraud excluded, the problem lies in determining the just price, that is, the one that equals the value of the thing. 
Cendejas Bueno, José Luis (2021), Justice and just price in Francisco

de Vitoria's Commentary on Summa Theologica II-II q77,

The Journal of Philosophical Economics: Reflections on Economic and Social Issues,

XIV (1-2), 1-32

In addition to its essence, it is necessary to attend to the circumstances that, accidentally, could make a purchase unfair because one of the parties received utility and the other damage. This happens when someone is in great need of the thing that they are going to get rid of, or when they will receive a great benefit from the thing they wish to acquire. In case of damage to the seller, the price may be greater than the value of the thing as compensation [26], although not higher than the value it has for him. However, if it is the buyer who obtains a large profit without disadvantage for the seller, this does not justify a price higher than the value of the thing: the seller cannot charge for something that does not belong to him, that is, the profit that the buyer receives as a result of his own circumstances [27]. Although, to demonstrate his integrity, the buyer could spontaneously give the seller something more.

Francisco de Vitoria begins his commentary on q77 with a brief summary of this. He highlights the fundamental difference between what the sale is in its essence, without fraud or deception, in which the price must equal the value of the thing, and what can happen accidentally, which is that this equality does not occur. When it is established that the just price is that which equals the value of the thing, the heart of the question then lies in what the value of the thing is. Following the Aristotelian reasoning, Vitoria states that natures of the things exchanged, one of them usually money, are different, so they cannot be made equal: it is through the price in money how men determine common estimation, or through an agreement. This principle also applies to money itself, whose nature does not consist in always having the same value. The value of money is also affected by human estimation: 'it is not necessary to consider if this is gold and the other silver, but the estimation of men'. Vitoria seems to follow here the metallist (or substantialist) theory of money, a characteristic of Aristotelian thought, although he does not derive all analytical consequences of this statement. Other members of the School of Salamanca will do so, such as Martín de Azpilcueta, Domingo de Soto, Tomás de Mercado or Juan de Mariana [28].

In commenting on justice (comment on STh II-II, q58, a3), Vitoria already anticipated that justice was the virtue that dealt mainly with exchanges between men, including commerce. He wonders then, why we do not praise the merchants who engage in acts of virtue, buying and selling justly? Trade is a dangerous 
Cendejas Bueno José Luis (2021), Justice and just price in Francisco

de Vitoria's Commentary on Summa Theologica II-II q77,

The Journal of Philosophical Economics: Reflections on Economic and Social Issues,

XIV (1-2), 1-32

vocation because it is difficult to stay in the golden mean but 'if the merchants do their trade well, their acts are virtuous and worthy of praise'. This statement sums up the spirit of Vitoria when dealing with mercantile activity. This view surpasses the 'certain debasement' that trade entails, according to Aquinas (STh II-II, q77, a4).

Profit occurs when the sale price exceeds the purchase price (STh II-II, q77, a4). The doubt about the legality of profit affects the commercial activity in which the physical transformation of a raw material into a final product (i.e., an intrinsic change) is not appreciated [29]. It is worth looking at Thomas Aquinas' doctrine on trade to appreciate Vitoria's progress, although always within the limits set by the master. Trade itself is not illicit, the vices of trade come from man and not from the art itself, says Aquinas, citing Augustine (STh II-II, q77, a4). Aquinas repeats Aristotle's arguments about trade. Exchange can be natural (Aristotle's natural chrematistics) either by way of barter or by money when it is produced to meet life's needs. Although commerce in its essence lacks an honest or necessary element, there is nothing in it that is vicious or dishonest. Profit earned for a necessary and honest purpose is therefore lawful. It happens when the moderate profit goes to supporting families or helping the needy, or if trade serves the public interest by providing the country with necessary amenities or services [30]. In this case, profit is no longer sought as an end goal, but rather as a compensation for labour. Thomas Aquinas (STh II-II, q77, a4 ad1) states that it is lawful to sell at a higher price than that at which the merchandise was acquired if it has been improved by labour (in that case, the difference would appear to be the price of labour) or if profit is not sought as an ultimate goal but rather in accordance with another necessary or honest purpose. It is lawful to sell at a higher price if this was not what was sought (STh II-II, q77, a4 ad2), that is, if those who benefit from an increase in the value do so as a consequence of improvements in the thing, of price variations due to time and place differences (extrinsic change), or due to the risk of transporting the thing from one place to another. That is, the illegality lies in the fact that one buys to sell at a higher price without adding anything or without any circumstance having change, the profit being the exclusive and ultimate purpose. 
Cendejas Bueno, José Luis (2021), Justice and just price in Francisco

de Vitoria's Commentary on Summa Theologica II-II q77,

The Journal of Philosophical Economics: Reflections on Economic and Social Issues,

XIV (1-2), 1-32

In his commentary, Vitoria affirms that profit, the pursuit of wealth as an end in itself without pursuing an honest end, is shabby and illegal. Negotiating in this way is dangerous, leading to temptation and deceit (1 Tim 6:9) and it is hard for a rich man to enter the kingdom of heaven' (Mt 19:23). It is, however, a venial sin if there is no intent to harm others. It is not a mortal sin because trading is not opposed to God's charity nor that of fellow men, nor any special precept. It would be a mortal sin if there is an insatiable and infinite desire, but not if it is to accumulate wealth for one's children (2 Cor 12:14).

With regard to traders selling at retail price without modifying the merchandise either in terms of time or location, Vitoria questions if it is lawful that they sell for a higher price than the cost. It is lawful if there is a change in location (transport) because the republic's needs could not be met otherwise. It is also lawful if time has passed, if a raw material has been transformed, or if the way of selling changes: if, for example, items are bought wholesale (por junto) and are sold at retail (por menudo). But it is not permissible the business of traders (the so-called recatones) who buy merchandise to who are carrying it to the city and sell it before them at a higher price without modifying it in any way. These traders must be expelled from the republic and kept away from business.

Vitoria concludes that transactions are illicit if they add nothing and take advantage of buying cheaply and selling at a higher price without even passing the time, and with the sole purpose of obtaining a profit. It is possible to act in this way because the just price covers an interval (it has extension, see below) and this transaction can take advantage of this margin to obtain some profit. But this does not make it fair because it harms the true buyer, the person who needs the thing, by raising the price, [31] as well as the vendor who works in a lawful manner. Although this negotiation is unlawful, it is not necessary to reimburse the person who bought it last because it is assumed that, in any case, the vendor has acted within the margin of the just price. The way in which this operation is performed determines whether it is a mortal or a venial sin. If it is a purchase by a single buyer who monopolizes the merchandise and then sells it at a higher price, it is a mortal sin, and those who behave in this way should compensate the republic for the damage they cause. If the purchase, with the intention of resale, is accidental, it is a venial sin if, in so doing, it prevents the person who needs 
Cendejas Bueno José Luis (2021), Justice and just price in Francisco

de Vitoria's Commentary on Summa Theologica II-II q77,

The Journal of Philosophical Economics: Reflections on Economic and Social Issues,

XIV (1-2), 1-32

the thing from buying it. If this resale with profit occurs accidentally [32], without intending to sell more expensive, it is not a sin and there is no obligation to provide restitution.

Purchasing large quantities of merchandise (wheat, for example) to later sell it at a higher price is a serious sin and there is an obligation to provide a refund. This is established by civil laws and natural and divine law. There is no contradiction in the fact that the benefit that a few obtain remains in the republic, since it is not lawful to benefit a few at the expense of many. But if those who buy the wheat then store it because the farmers cannot keep all the grain, this is deemed good so long as the harvest does not become more expensive as a result. Purchasing wheat in spring to sell it in May, when it will be more expensive, is dangerous because it induces greed. If an honest profit is expected, it is accepted, but this is not the case if it is done with bad intentions wishing evil on the republic in order that wheat becomes more expensive. Selling more cheaply than others is lawful provided it is done in good faith, and not with the intention of harming other sellers [33]. It is meritorious and of benefit for the republic.

Should the seller have knowledge of a future drop in price owing to a greater abundance of wheat, for example, the vendor is not obliged to lower the price, to remain in line with the current estimation, nor are they obliged to disclose it (commentary on STh II-II, q77, a3 ad4). Thomas Aquinas, for his part, points out that, being dutiful to justice, the vendor does not have to reveal the foreseeable price drop which would cause him losses, although he would demonstrate a more perfect virtue if he did so or if he lowered the price (following Cicero, De Officiis, III, 50). On the other hand, if a buyer, owing to his profession, is aware of a future increase in the price of specific merchandise (once again, wheat in the example), he is not obliged to reveal this to the person from whom he buys it cheaply today, nor to provide restitution in the future when the price has risen. In other words, under what was previously said, it is permissible to buy cheaply today and then sell at a higher price tomorrow, if both prices are based on the commonly accepted estimations at both times, and the just price is respected. 
Cendejas Bueno, José Luis (2021), Justice and just price in Francisco

de Vitoria's Commentary on Summa Theologica II-II q77,

The Journal of Philosophical Economics: Reflections on Economic and Social Issues,

XIV (1-2), 1-32

\section{Just price, market power, and legal price}

Aquinas did not stress the relationship between the degree of competition in the market, the establishment of the price and the nature of fairness; in other words, on the conditions that allow the price to match the value of the thing. Francisco de Vitoria, however, gave considerable thought to this question by considering the circumstances that prevent the common estimation of the just price from being reached. Vitoria states that, because the origin of the value is the common estimation, where there are many buyers and sellers, it is not necessary to worry about the price differences that occur between the moment when the merchandise is bought and when it is sold. The way in which the thing is sold influences the price. For example, it is logical that the price will be different when buying or selling either in bulk or at retail, so long as there is no fraud or deception, and it will be according the common estimation. Labour or risks that may have been involved between purchase and sale are of no interest: if there has been a variation in the common estimation, differences between the buying and selling prices are justified [34]. The just price is 'what it is worth in the market square' and that is what must be attended to. 'It is not legal to sell something at a higher price because it was bought at a higher price', states Vitoria [35].

If there are few buyers and sellers, the price of the thing cannot be fixed by the common estimation and Conrad's considerations [36] should be taken into account: expenses, labour, risk and scarcity which raise the price must be weighed so that the seller can establish a reasonable price. Conrad's fifteen considerations regarding the just price and fair value of the thing work before the price has been established by common estimation, but not as a substitute for it. If there are many sellers and either few buyers or just one buyer, the common estimation should not be taken into consideration, but rather reasonable grounds according to the 'discretion of an honest man' (arbitrium boni viri). If there is only one buyer, it is not lawful for him to take advantage of a vendor who needs to sell. If there are several buyers, however, the resulting price is that of common estimation and is therefore lawful. Collusion agreements that lead to the creation of a monopoly or a monopsony are fraudulent and require restitution. 
Cendejas Bueno José Luis (2021), Justice and just price in Francisco

de Vitoria's Commentary on Summa Theologica II-II q77,

The Journal of Philosophical Economics: Reflections on Economic and Social Issues,

XIV (1-2), 1-32

With regard to sell as expensive as possible ('res tantum valet quantum vendi potest, Dig. 36.1.1.16, 13.1.14pr, 39.6.18.3, 47.2.52.29), without fraud, deceit or ignorance, Vitoria states that it should be considered whether the item is of basic need. This can cause the circumstance of 'mixed voluntary' to occur, which makes the existence of market power especially harmful (see below concerning the tasa del pan, a ceiling price for bread). When there are many sellers, it is lawful to sell in this way in accordance with the established and common price [37]. It is not lawful, however, if there are few vendors. For adornments or curiosities, it is lawful to sell as expensive as possible if there is full consent, but not if there is necessity or violence. In the absence of these, however, merchandise can be sold for maximum profit, because there is no insult to the person who consents ('volenti ac consentienti non fit iniuria', Dig. 39.3.9.1): just as a person is not obliged to return a donation, nor are they obliged to make a refund when they receive a higher price than a thing is worth, provided that there is no deception, ignorance, necessity or fear; in other words, if there is full consent.

The fact that agents are subject to the price of common estimation does not detract from their personal responsibility. According to Thomas Aquinas, except in the case of fraud, buyers and sellers can buy and sell a thing for more or less than its value as long as the difference is not excessive according to what is established by positive law (see below). The fact that the price is determined by civil laws, however, does not make it permissible for buyers and sellers 'to deceive one another'. Human laws are given to the people, who are a mixture of the virtuous and those lacking in virtue, and the laws cannot forbid everything contrary to virtue but only that which destroys coexistence. What is not forbidden is lawful; not because it is approved, but because it is not punished, even though divine law leaves nothing that goes against virtue unpunished (STh II-II, q77, a1 ad1) [38].

Vitoria affirms the moral responsibility of the seller who must be aware of the market's current circumstances, although in principle they are outside from their individual scope. Thus, with regard to the price of wheat, Vitoria reminds us [39] that 'it is double the just price of the thing; namely, either that established by law or that established by custom'. In the same letter, Vitoria shows the nature of how a market works: 'And ex natura rei it is necessary that it be so: that by reducing 
Cendejas Bueno, José Luis (2021), Justice and just price in Francisco

de Vitoria's Commentary on Summa Theologica II-II q77,

The Journal of Philosophical Economics: Reflections on Economic and Social Issues,

XIV (1-2), 1-32

the wheat and sellers, with growing necessity, the price must rise'. Where there are many sellers, 'the price is made in its own right', hence whoever raises the price in the first place when there is a generalized shortage is somewhat accidental (i.e., it is owing to market circumstances for which the seller is not responsible). Even though, when there is scarcity, sellers should try to maintain a moderate profit and 'not do as much harm as they can to the poor'; that is to say, they should not sell the wheat 'at the highest possible price' (i.e., within the scope of personal responsibility) even if it were legal to do so.

Given that the objective of the Scholastics' analysis is the determination of the just thing, the price set by the authorities, or legal price, has priority over the common estimation price [40]. Like a just law, the legal price obliges in conscience and is the just price, although, according to Vitoria, it cannot be arbitrary but must adhere to the range determined according to what is right. He agrees, for example, with Azpilcueta (see Muñoz 1998, 173) and with Luis de Molina, for whom the legal price must respect the margin of extension of the natural price. The equivalence between price and the value of the thing is a feasible equality and is not exact: given the extension of the just price, exchanges at prices within the margin are lawful. Given that information is not concentrated in a single point of exchange during the actual functioning of a market, it cannot be expected that all transactions between buyers and sellers are made at the same price. So, the just price is not determined exactly (punctualiter), but, as it results from a rough estimate (in quadam aestimatione), it has an extension within which the equivalence required by justice is not destroyed (STh II-II, q77 ad1). The just price extends from a lower limit (pretium iustum pium) to an upper limit (pretium iustum rigidum) through an intermediate price (pretium iustum moderatum) [41]. In consideration of this, the schoolmen complied with the provisions of the Codex that limited the range of variation to which the parties could agree on the price. In fact, this margin was used to justify the collection of an interest for postponing the payment for a purchase, in this way avoiding the prohibition of usury: thus, for Vitoria, within the range of the just price, we can ask for something more if it is regularly sold on credit, without this constituting usury (comment to STh II-II, q78). 
Cendejas Bueno José Luis (2021), Justice and just price in Francisco

de Vitoria's Commentary on Summa Theologica II-II q77,

The Journal of Philosophical Economics: Reflections on Economic and Social Issues,

XIV (1-2), 1-32

The iustum pretium was any price that was freely agreed between buyer and seller who were allowed to bargain naturaliter (Dig. 4.4.16.4, 19.2.22.3). The Codex (4.44.2), however, limited this freedom by stating that if the seller sold for less than half the just price, he could oblige the buyer to pay the difference or dissolve the sale because he was subject to great harm (laesio enormis). Following Rothbard (1995, 32), this limitation affected estate (fundus) and did not influence subsequent laws. In the $12^{\text {th }}$ century, however, the French author of Brachylogus extended this principle to the sale of any goods (res), considering the Bolognese glossators as well as the Provençal Lo Codi that recognized the laesio enormis of a buyer who had paid more than double the just price (Rothbard 1995, 39-40), what Alberic would later include in his collection of canon law. Finally, Petrus Placentinus reduced the allowed excess to about half of the just price, which was then accepted in the $13^{\text {th }}$ century by Azo, Accursius, and Odofredus. Should such a difference occur, the beneficiary is obliged to refund the injured party. Vitoria points out the possibility that human laws, the king, or the judge, could determine the absence of the obligation to provide restitution should the merchandise be bought or sold in more or less than half of the just price. In line with this legal tradition, however, Vitoria affirms the unlawfulness of such a law which would be iniquitous and dangerous. Consequently, the price set by human law, to be just, should not deviate from the established margin.

In Spain, during the $16^{\text {th }}$ and $17^{\text {th }}$ centuries, the fixing of a legal price that aroused the greatest controversy was the tasa del pan [42], which was in force with various adjustments and waivers between 1539 and 1632 (see Del Vigo 1981; Gómez Camacho 1986, 1992). This was a maximum fixed price for wheat, an essential food, the price of which was subject to the irregular harvests typical of the drought cycle in the Mediterranean basin. Melchor de Soria favoured the convenience of the legal price according to the changing conditions of the market and to the differences between the capacity of large and small owners for storing wheat. In the years when there was a bad harvest, the price rose, and the big owners enjoyed market power. The humbler consumers and the small owners, who needed the grain to sow the next crop, were inevitably subject to high prices given the pressing need for this grain. At such prices, the exchange was 'mixed voluntary' owing to great asymmetry between the needs of sellers and buyers. This made it advisable to fix the price: 'the price is not natural, but violent, 
Cendejas Bueno, José Luis (2021), Justice and just price in Francisco

de Vitoria's Commentary on Summa Theologica II-II q77,

The Journal of Philosophical Economics: Reflections on Economic and Social Issues,

XIV (1-2), 1-32

because of the violence that sellers do and the one that buyers receive' (Gómez Camacho 1986, 47). However, suppressing the fixed price solely for the group of small owners was the right thing if it encouraged the expansion of the crop by taking advantage of the 'delicious greed' of the farmers. Azpilcueta (Muñoz, 1998, 184) opposed the fixing of a maximum price, except in exceptional circumstances, and pointed out drawbacks such as the promotion of fraudulent behaviour, its uselessness in times of abundance or its simple violation in times of hardship. Luis de Molina opposed the tasa (La teoría del justo precio, disp. 365, n. 14), agreeing with Vitoria that the legal price must be included within the margin of the natural price, which then has priority.

In Scholastic thought, the determination of the just wage was treated in the same way as that of the just price: it results from the common estimation in symmetrical conditions of necessity on both sides of the market. It also applies to the setting of a doctor's or a lawyer's fees. Vitoria asserts that a man who pays his servant less than half his just wage [43] is obliged to restore it, even if the servant accepts the reduced pay, as there may have been necessity and, therefore, the consent was not fully voluntary, but entailed a mixture of something involuntary.

\section{Final considerations}

We have seen that Vitoria, like the other schoolmen, considers buying and selling to be a mutually agreed transaction among equals, which must therefore conform to the strict equivalence of the exchanged things as to a principle of natural law. The determination of the equivalence of things that, by their nature, are different, is resolved according to a feasible valuation resulting from a common estimation whose fundamental characteristic is that it emerges from a sufficient concurrence of agents who buy or sell with full consent. The price (or rather, a range of prices) that arises from these circumstances preserves justice. Profit derived from commercial activity is lawful if it aligns with the reasons listed by Thomas Aquinas: basically, profit must serve the family or the political community, be moderate and not an end in itself, and come from a business activity that adds something. The assumption that the profit is derived from 
Cendejas Bueno José Luis (2021), Justice and just price in Francisco

de Vitoria's Commentary on Summa Theologica II-II q77,

The Journal of Philosophical Economics: Reflections on Economic and Social Issues,

XIV (1-2), 1-32

buying and selling at just prices could be added. In his commentary on q. 77, it cannot be said that Vitoria's thought to be particularly original in relation to that of Thomas Aquinas. However, Vitoria displays a greater appreciation and understanding of trading activities as well as, on the explanatory level, a greater vividness and didactic capacity owing to the fact that the text is the written transcription of his lessons.

Vitoria continues the medieval Scholastic tradition by requiring that the just price results from a sufficient concurrence of sellers and buyers, since this limits the ability to take advantage of the need on the other side of the market. The authorities can fix prices but, in so doing, must abide by what is established by the margin of the just price. This tradition is in line with the principles of Roman law with regard to consent in the agreements of sale that include the absence of violence, fraud or deception. But, in the Scholastic analysis, the juridical aspect is integrated into a moral perspective which is broader and more demanding. In this respect, the analysis of the circumstances that must be present in order that an exchange takes place with full consent is of great concern. The absence of compulsion is only possible with symmetrical necessity on both sides of the market, with the just price being that which complies with this requirement. Whether or not there is sufficient level of concurrence, Vitoria always appeals to the morally responsible actions of buyers and sellers to seek justice in exchanges.

Acknowledgements: This work is result of the project 'Sociedad, política y economía: proyecciones de la Escolástica española en el pensamiento británico y anglosajón' (Programa Estatal de Fomento de la Investigación Científica y Técnica de Excelencia, reference no.: FFI2017-84435-P), funded by the Agencia Estatal de Investigación (AEI) and the European Regional Development Fund (ERDF). I am also grateful for the comments of two anonymous referees, which have helped to improve this work. 
Cendejas Bueno, José Luis (2021), Justice and just price in Francisco

de Vitoria's Commentary on Summa Theologica II-II q77,

The Journal of Philosophical Economics: Reflections on Economic and Social Issues,

XIV (1-2), 1-32

\section{Endnotes}

[1] In 2017, San Esteban editions published a comprehensive, annotated bilingual edition of the Relectiones. In English, we mention Pagden and Lawrance's edition (1991). The works On the American Indians (De Indis, 1539) and On the Law of War (De Iure Belli, 1539) are the most edited and commented Vitoria's Relectiones. As a consequence of recognizing the American Indians as subjects of rights, both the existence of a universal political community which included all peoples - communitas totius orbis - and a corresponding universal common good were defended (Pereña 1984, 1986, 1992).

[2] The rediscovery of Vitoria's contributions in the field of international law began with the works of Ernest Nys (Le droit de la guerre et les précurseurs de Grotius, 1882; Les publicistes espagnols du XVIe siècle et les droits des Indiens, 1890; Le droit des gens et les anciens jurisconsultes espagnols, 1914; Francisco de Vitoria's De Indis et De iure belli Relectiones, 1917) and James Brown Scott (The Spanish origin of international law: Francisco de Vitoria and his law of nations, 1934). See also Hernández $(1977,1995)$ and the bibliographic references collected by Pena (2009, 384).

[3] For a further analysis of this issue, see Cendejas (2020).

[4] In both De mare liberum (Leiden, 1609, chapter XII of De iure praedae) and De iure belli ac pacis (Paris, 1625), Hugo Grotius frequently cites Francisco de Vitoria, Fernando Vázquez de Menchaca and Diego de Covarrubias, among other Spanish schoolmen, see Gómez Rivas (2005a,b; 2013a,b). Rights inspired by Vitoria, such as the right to communicate and trade with other peoples and the freedom of navigation for all nations, are asserted in De mare liberum.

[5] Vitoria discussed De iustitia et iure during the 1527-28 and 1535-36 academic years. Manuscript no. 43 at the University de Salamanca, notes of student Francisco Trigo, relates to the academic year 1935-36. Beltrán de Heredia's edition is based on it, as the one of Francisco de Vitoria (2006) which we follow in this work.

[6] The similarity of approaches and ideas of various members of the School was previously indicated by Sayous (1928). 
Cendejas Bueno José Luis (2021), Justice and just price in Francisco

de Vitoria's Commentary on Summa Theologica II-II q77,

The Journal of Philosophical Economics: Reflections on Economic and Social Issues,

XIV (1-2), 1-32

[7] The list of authors and works considered by Grice-Hutchinson includes Francisco de Vitoria (1483-1546, Comentarios de la Secunda Secundae, 1535), Domingo de Soto (1494-1560, De iustitita et iure, Salamanca, 1553), Domingo Báñez (1528-1604, De iure et iustitia decisiones, Salamanca 1594), Juan de Medina (1489-1545, Codex de restitutione et contractibus, Alcalá, 1546), Martín de Azpilcueta (1492-1586, Comentario resolutorio de cambios, Salamanca, 1556), Diego de Covarrubias (1512-1577, Veterum numismatum collatio, Salamanca, 1550), Luis Saravia de la Calle (Instrucción de mercaderes muy provechosa, Medina del Campo, 1544), Luis de Alcalá (Tratado de los préstamos que pasan entre mercaderes y tratantes, Toledo, 1543), Cristóbal de Villalón (Tratado de cambios y reprobación de usura, Valladolid, 1542), Tomás de Mercado (c. 1530-1575, Suma de tratos y contratos, Salamanca, 1569; Seville, 1571), Francisco García (1525-1583, Tratado utilísimo y muy general de todos los contratos, Valencia, 1583), Bartolomé Frías de Albornoz (Arte de los contratos, Valencia, 1573), Juan de Salas (1553-1612, Commentarii in secundam secundae D. Thomae de contractibus, Lyon, 1617), Luis de Molina (1535-1600, De iustitia et iure, Cuenca, 1597), Pedro de Valencia (1555-1620, Discurso sobre el precio del trigo, 1605), Martín González de Cellorigo (1570-1620, Memorial de la política necesaria y útil restauración a la república de España, Valladolid, 1600), Leonard Lessius (1554-1623, De iustitia et iure, Leuven, 1605) and Juan de Lugo (1583-1660, De iustitia et iure, Lyon, 1642).

[8] The explanation of the economic value based on the ability of goods to satisfy human needs is generalized in Scholastic thought. It is commonplace to point out the existence of two scales of value. Thus, in a widely used example by schoolmen, according to the natural order of the created beings, mice occupy a place superior to wheat, but according to its esteem as a useful thing, nobody prefers mice to wheat (Augustine, De Civitate Dei XI, 16).

[9] Jean Bodin (Réponses au Paradoxes de M. de Malestroit touchant le fait des monnaies et l'enrichissement de toutes choses, Paris, 1568) and Nicolaus Copernicus (Monetae Cudendae Ratio. This work was initially expounded in 1522 before the Prussian assembly. It was in manuscript in 1526 but not edited until 1864 in Paris. Copernicus affirms that 'money normally depreciates where it is too abundant'. 
Cendejas Bueno, José Luis (2021), Justice and just price in Francisco

de Vitoria's Commentary on Summa Theologica II-II q77,

The Journal of Philosophical Economics: Reflections on Economic and Social ISsues,

XIV (1-2), 1-32

[10] In addition to Tomás de Mercado and Bartolomé Frías de Albornoz, who lived in both Mexico and Spain, this School included Juan de Matienzo (Commentaria in librum quintum recollectionis legum Hispaniae, Madrid, 1580), Luis López (Instructorium conscientiae, Salamanca, 1585; Tractatus de contractibus et negotiationibus, Salamanca, 1589), Pedro de Oñate (De contractibus, Rome, 1646-1654), Diego de Avendaño (Thesaurus Indicus, Antwerp, 1668-1686) and Domingo Muriel (Rudimenta iuris naturae et gentium, Venice, 1791). In addition to Azpilcueta, both Mercado and Matienzo independently formulated the quantity theory of money.

[11] For example, in Gordon (1975), Baeck (1994), Rothbard (1995), Fuentes (1999) and Perdices (2008). The relevance of Spanish Scholastic economic thought is also shown in Grice-Hutchinson (1952, 1978, 1993), Gómez Camacho (1998a, b), Tedde and Perdices (1999), Vigo (1997, 2006) and Alves and Moreira (2013).

[12] With regard to Vitoria's just price theory, we must mention the works of Iparraguirre (1957) and González (1998). Vitoria's approach to the just price can be compared to the one followed by, among others, Martín de Azpilcueta (see Muñoz, 1998, Ch. 5), Juan de Lugo (Monsalve, 2010), Tomás de Mercado (Suma de Tratos y contratos II) and Luis de Molina. Questions relating to the just price of Molina's treatise De iustitia et iure were published by Gómez Camacho under the title La teoría del justo precio, 1981.

[13] For Celsus, ius is the art of the good and the equitable (Dig. 1.1.1pr).

[14] Both definitions are from Ulpian: 'Iustitia est constans et perpetua voluntas ius suum cuique tribuendi (Dig. 1.1.10pr) and 'Iuris praecepta sunt haec: honeste vivere, alterum non laedere, suum cuique tribuere' (Dig. 1.1.10.1).

[15] Political justice can be natural or legal. Natural justice has the same force everywhere and is not subject to human opinion, whereas legal justice is distinguished either by its promulgation or by application to particular cases (Nic Eth V, 1134b20-25). This division is manifest in the price: the natural just price must be differentiated from the legal just price, as we will see later. 
Cendejas Bueno José Luis (2021), Justice and just price in Francisco

de Vitoria's Commentary on Summa Theologica II-II q77,

The Journal of Philosophical Economics: Reflections on Economic and Social Issues,

XIV (1-2), 1-32

[16] Thomas de Vio, Cardinal Cajetan (1469-1534), Dominican, who also commented on Aquinas' Summa Theologica, is the author of the De Montes Pietatis (1498), De Cambiis (1499) and De usura (1500). Rothbard (1995, 99-101) highlights his market-prone positions by calling him 'liberal-Thomist'.

[17] The reception in the Latin Middle Ages of the paragraphs of the Book V of the Nicomachean Ethics, that synthesize the Aristotelian theory of value, is explained in detail in Langholm (1979). Langholm differentiates six interpretative traditions based on Robert Grosseteste, Albert the Great, Thomas Aquinas, Henry of Friemar, John Buridan and Gerald Odonis, respectively. Grosseteste usually translates the term $\chi \rho \varepsilon 1 \alpha$ as the Latin indigentia, but also as usus, utilitas, opus or necessitas.

[18] Theft implies a hidden appropriation along with ignorance of the one who is stolen. Robbery is an appropriation carried out clearly and through violence (STh II-II, q66, a4). Theft and robbery share the fact of being involuntary to the victim, either through ignorance in the first, or through violence in the second. Robbery also results in some injury to the person.

[19] History of Economic Analysis, 93, footnote no.15. Not only Romanists and Canonists, but also the theologians who wrote before Aquinas understood that the just price was the price of a market with high concurrence of bidders and claimants (Baldwin 1959). For Langholm (1998b, 469), the fact that the just price is the competitive price prevents a buyer or a seller from taking advantage of their needy counterpart. The competitive market offers protection against compulsion because no one can force another to pay a price other than the just one: competition between sellers protects buyers and vice versa.

[20] In this way, articles 2 and 3 of q. 77, which we will not comment on here, deal with injustice because of the thing sold when it is affected by faults or defects and the obligation to declare them or to adjust the price if necessary. In current terms, we could say that they deals with asymmetric information issues.

[21] Obviously, these are current terms that Vitoria does not use. Vitoria, however, sometimes refers to the presence of a monipodio (roughly translated as gang), meaning 'agreement of people who associate and conspire for illicit purposes' (Dictionary of the Spanish Royal Academy). 
Cendejas Bueno, José Luis (2021), Justice and just price in Francisco

de Vitoria's Commentary on Summa Theologica II-II q77,

The Journal of Philosophical Economics: Reflections on Economic and Social Issues,

XIV (1-2), 1-32

[22] On this subject, it should be noted that, for Thomas Aquinas, violence is more directly opposed to the will than ignorance. Hence, it is more serious (STh II-II, q66, a9). In society, no one can use coercion except by public authority (STh II-II, q66, a8). It is up to princes to maintain justice. Hence, the use of violence or coercion must be in accordance with the demands of justice, for example, violence must be against enemies or evildoers, and if not, public authority is bound to make restitution.

[23] The Roman legal and canonical doctrine understood the just price as that to which it was commonly sold (communis aestimatio). This doctrine was shared by theologians and schoolmen since medieval times. For example, Jean Buridan, ('rei venalis mensura est communis indigentia humana'), Alexander of Hales (just estimation of the goods is as it is sold commonly in that city or place in which the sale occurs') or Albert the Great ('a price is just which can equal the value of the goods sold according to the estimation of the market place at that time', cited from Rothbard 1995). For Bernardino of Siena, the just price comes from 'the common valuation or estimation made collectively by the community of citizens' (from De Roover 1967, 20). Cajetan concluded that for Aquinas, the just price is 'the one that, at a specific moment, can be obtained from the buyers, assuming common knowledge and in the absence of all fraud and coercion' (from De Roover 1958, 422-423). For Diego de Covarrubias, the value of an article does not depend 'on its essential nature but on the estimation of men, even if that estimation be foolish. Thus, in the Indies wheat is dearer than in Spain because men esteem it more highly, though the nature of the wheat is the same in both places' (cited from Grice-Hutchinson 1952, 48). For Tomás de Mercado, the just price 'is the one that is paid in cash publicly and is used this week and this time, as they say in the square, there being neither force nor deception; although it is more variable, as experiences teaches us, than the wind' (Suma de tratos $y$ contratos II, 8, 181).

[24] Practically all the schoolmen claim that the just price is the common estimation and not the one that covers costs. De Roover (1958) proceeds to clarify many misunderstandings in this regard. The exceptions that are usually adduced in the figures of Albert the Great, Aquinas and Duns Scotus would not be such according to Langholm (1998b, 470-475) as both principles of estimating 
Cendejas Bueno José Luis (2021), Justice and just price in Francisco

de Vitoria's Commentary on Summa Theologica II-II q77,

The Journal of Philosophical Economics: Reflections on Economic and Social Issues,

XIV (1-2), 1-32

the just price are complementary: if the price of common estimation does not cover costs, production cannot take place. Albert the Great (Ethica V, 2, 7) and Aquinas (Comment in $X$ libros Ethicorum, lib. V, lect. 7, 8) make this point in commenting on Aristotle's Ethics.

[25] When there is a useful friendship between the buyer and the seller, the equality of the thing should not be attended to, but rather the equality of profit or utility (Nic Eth VIII, 1163a16 and STh II-II, q77, a1 ad3).

[26] This also applies to justify the payment of an interest in a loan contract (mutuum) as an extrinsic title: it is lawful to hold oneself harmless (damnum emergens). Said in current terms, the interest would be a risk premium.

[27] Thomas Aquinas states that it is not permissible to appropriate the surplus of the consumer (the practice that modern economic theory calls price discrimination) and that is only possible when there is market power. Both Scholastic thought and the policy of the cities concerning price regulation condemned the formation of monopolies and price discrimination (see De Roover 1958).

[28] Concerning Azpilcueta, Molina and Mariana, see Grabill (2007).

[29] In addition to prohibiting clerics from trading, the Decretum Gratiani (ca. 1140), recalls the expulsion of merchants from the temple by Christ and states that the merchant can hardly or can never please God and that no one can buy and sell without lying and perjury (John Chrysostom's commentary on the Gospel of Matthew, Decretum, pars 1, dist. 88, C. 10,11). The merchant is the one who buys to obtain a profit, selling the thing without any modification, not who uses it as a matter to manufacture something out of it. Buying at the time of grain or wine harvest, not out of necessity but out of greed, paying two denarii per modius, and reserving it for when it is sold for four or six, is clumsy profit (turpe lucrum, Decretum, pars 2, C.14, q 4, C. 9). For Alexander of Hales, trade may be illegal or lawful according to its concomitant circumstances. Strictly speaking (secundum se), it is neither lawful nor unlawful: following Augustine, 'trading is sometimes lawful' (Summa Theologiae, from Sierra 1975, 307). For Bonaventure, following Pope Gregory I, the fault is not in the wealth, but in its affection. However, wealth gives chance of guilt because it tilts to evil and 
Cendejas Bueno, José Luis (2021), Justice and just price in Francisco

de Vitoria's Commentary on Summa Theologica II-II q77,

The Journal of Philosophical Economics: Reflections on Economic and Social Issues,

XIV (1-2), 1-32

distracts from the good (Apologia pauperum, 1269, from Sierra 1975, 339-340). But also, earthly possessions are useful for the sustenance of nature, for the works of human industry and, in some, for the exercise of perfect virtue. This does not come from the riches themselves, but from the one who uses them.

[30] Bernardino of Siena in his De Evangelio aeterno (Spiers, 1484) mentions three types of traders useful to the community: importers and exporters (mercantiarum apportatores), those who store merchandise (mercantiarum conservatores) and those who transform them by improving them (mercantiarum immutatores seu melioratores) (see De Roover 1967, 11).

[31] The extension of the just price results from the conditions that actually exist in the market. This makes the trading operations of the recatones (that Vitoria condemns for not adding anything to the merchandise) possible.

[32] Something similar is recounted in the fifth and sixth cases of Parecer sobre cambios y finanzas de los Doctores de París (1530), an enquiry into changes by the Spanish merchants of Antwerp and the response of Paris doctors. In these cases, the question is asked about the legality of taking advantage of the variation in price that may occur during the period between when the purchase on credit (al fiado) is made and the moment when the transaction is settled. According to Vitoria, it is not strictly speaking usury, despite appearances, because in principle there is no intention of gain by the mere passage of time (Francisco de Vitoria 2006, 296-297; report partially translated by GriceHutchinson 1952, 120-126).

[33] It can be understood that Vitoria is referring to what we would call a price war in which the competitor is ousted to obtain monopoly power.

[34] See also Azpilcueta (Manual de confesores, see Muñoz 1998, 165-166). He refers to the statement of the jurist Paulus: 'pretia rerum non ex affectu, nec utilitate singulorum, sed communiter funguntur' (Dig. 35.2.63).

[35] Bernardino of Siena (De Roover 1967, 21) also affirms that the merchandise must be sold at the price of common estimation, even if this means a loss, based on what was said by Raymond of Pennaforte and Henricus of Susa. Saravia de la Calle explains it clearly: 'For the just price arises from the abundance or 
Cendejas Bueno José Luis (2021), Justice and just price in Francisco

de Vitoria's Commentary on Summa Theologica II-II q77,

The Journal of Philosophical Economics: Reflections on Economic and Social Issues,

XIV (1-2), 1-32

scarcity of goods, merchants, and money, as has been said, and not from costs, labour, and risk. If we had to consider labour and risk to assess the just price, no merchant would ever suffer loss, nor would abundance or scarcity of goods and money enter into the question. Prices are not commonly fixed on the basis of costs (...) The just price is found not by counting the cost but by the common estimation' (from Grice-Hutchinson 1952, 82).

[36] In De contractibus, III, q56. Conrad Summenhart (1450-1502) was a Dominican who taught at the University of Tübingen, and author of Opus septipartitum de Contractibus (Haguenau, 1500).

[37] Given that the market price imposes a ceiling on the bidders. Remember what has been said regarding Schumpeter's interpretation of the just price. Langholm (1998a, 79-80; 1998b, 459-470) lists the interpretations and additions to this principle made by Romanists, Canonists and theologians, among others: a thing is worth as much as it can be sold for 'if so permitted' (Antonino of Florence), 'if sold at a just price' (Battista Trovamala), 'justly and reasonably' (Gabriel Biel), 'lawfully' (Summenhart), 'lawfully and reasonable' (Juan de Medina), 'within the limits of just estimation' (Lessius).

[38] Also, in Quodlibet II, q5, a2 (from Langholm 1998b, 462): 'the precepts of law...permit certain minor sins, inflicting no punishment for them...and among these is the deception (deceptio) which occurs between sellers and buyers'.

[39] Letter to Miguel de Arcos of April 28, 1546 (Francisco de Vitoria 2006, 266).

[40] Also, for Tomás de Mercado (Suma de Tratos y contratos I, 3, 77) and for Luis de Molina, who follow the Aristotelian division between natural and legal. The price is natural because it is born of the same things, independently of any human law or public decree, but depending on many circumstances with which it varies, and of the affection and esteem that men have for things according to the different uses for which they serve' (La teoría del justo precio, disp. 347, n. 3).

[41] Bernardino of Siena also stated that the just price extended between two extremes points around a medium point (pius, discretus, rigidus in Sermo 34, a3, c1). Juan de Lugo asserted that the just price, as an exact value, can only be known by God 'pretium iustum mathematicum licet soli Deo notum' (De iustitia 
Cendejas Bueno, José Luis (2021), Justice and just price in Francisco

de Vitoria's Commentary on Summa Theologica II-II q77,

The Journal of Philosophical Economics: Reflections on Economic and Social Issues,

XIV (1-2), 1-32

et iure). Hayek, along with De Lugo, mentions Juan de Salas (Commentarii in secundam secundae) in relation to the information problem that markets solve: 'quas exacte comprehendere et pondedare Dei est non hominum'.

[42] Melchor de Soria (1558-1643), author of Tratado de la justificación y conveniencia de la tassa del pan, 1627; plus, some Adición, 2nd ed., 1633, both edited in Toledo.

[43] Antoninus of Florence (De Roover 1967, 24) noted that the commonly occurring situation was of greater need on the part of workers, which forced them to accept a lower salary than of the common estimate. The legality of brotherhoods or trade unions did not follow from this.

\section{References}

Aquinas, Thomas ([1273] 1947), Summa Theologica, New York: Benziger Brothers.

Alves, André A., and José M. Moreira (2013), The Salamanca School, New York: Bloomsbury.

Aristotle (1925), Nicomachean Ethics. In The Works of Aristotle, edited by William D. Ross and John A. Smith, vol. IX, Oxford: Clarendon Press.

Baeck, Louis (1994), The Mediterranean Tradition in Economic Thought, London: Routledge.

Baldwin, John W. (1959), The Medieval Theories of the Just Price: Romanists, Canonists, and Theologians in the Twelfth and Thirteenth Centuries, Transactions of the American Philosophical Society, New Series XLIX (4), Philadelphia: The American Philosophical Society.

Barrientos, José (2005), “Aproximación histórica al concepto 'Escuela de Salamanca”, Salmanticensis, 52, 69-119.

Barrientos, José (2011), Repertorio de moral económica (1526-1670). La Escuela de Salamanca y su proyección, Pamplona: Eunsa. 
Cendejas Bueno José Luis (2021), Justice and just price in Francisco

de Vitoria's Commentary on Summa Theologica II-II q77,

The Journal of Philosophical Economics: Reflections on Economic and Social Issues,

XIV (1-2), 1-32

Belda, Juan (2000), La Escuela de Salamanca y la renovación de la teología en el siglo XVI, Madrid: Biblioteca de Autores Cristianos.

Cendejas, José Luis (2020), 'Derecho subjetivo, naturaleza y dominio en Francisco de Vitoria', Cauriensia, 15, 109-137.

Cendejas, José Luis, and Cecilia Font (2015), 'Convergence of inflation with a common cycle: estimating and modelling Spanish historical inflation from the 16th to the 18th centuries', Empirical Economics, 48(4), 1643-1665.

Chafuen, Alejandro A. (2003), Faith and Liberty: The Economic Thought of the Late Scholastics, Maryland: Lexington Books.

Fuentes, Enrique (ed.) (1999), 'La Escuela de Salamanca y las ideas económicas de la Escolástica', in Economía y Economistas Españoles, edited by Enrique Fuentes, vol. 2, Barcelona: Galaxia Gutenberg.

Gómez Camacho, Francisco (1986), 'Precio natural y precio legal en el mercado del trigo. El pensamiento económico de Melchor de Soria', in Aportaciones del pensamiento económico iberoamericano, siglos XVI-XX, Madrid: Ediciones Cultura Hispánica.

Gómez Camacho, Francisco (1998a), Economía y filosofía moral: la formación del pensamiento económico europeo en la Escolástica española, Madrid: Síntesis.

Gómez Camacho, Francisco (1998b), 'Later Scholastics: Spanish economic thought in the XVIth and XVIIth centuries', in Ancient and Medieval Economic Ideas and Concepts of Social Justice, edited by S. Todd Lowry, and Barry Gordon, Leiden: Brill.

Gómez Rivas, León (2002), 'Marjorie Grice-Hutchinson y los orígenes del liberalismo en España', La Ilustración Liberal, 11, 81-90.

Gómez Rivas, León (2005a), 'Economía y guerra: el pensamiento económico y jurídico desde Vitoria a Grocio (y después)', Studia Historica. Historia moderna, $27,135-159$.

Gómez Rivas, León (2005b), 'La Escuela de Salamanca, Hugo Grocio y el liberalismo económico en Gran Bretaña', Torre de los Lujanes, 55, 217-227. 
Cendejas Bueno, José Luis (2021), Justice and just price in Francisco

de Vitoria's Commentary on Summa Theologica II-II q77,

The Journal of Philosophical Economics: Reflections on Economic and Social Issues,

XIV (1-2), 1-32

Gómez Rivas, León (2013a), 'Adam Smith: algunos antecedentes olvidados', Procesos de Mercado, 10(2), 73-98.

Gómez Rivas, León (2013b), 'Influencia de Diego de Covarrubias en la obra de Hugo Grotius (Mare Liberum, 1609)', Procesos de Mercado, 10(2), 321-342.

González Fabre, Raúl (1998), Justicia en el mercado. La fundamentación de la ética del mercado según Francisco de Vitoria, Caracas: Universidad Católica Andrés Bello.

Gordon, Barry (1975), Economic analysis before Adam Smith: from Hesiod to Lessius, London: MacMillan Press.

Grabill, Stephen J. (ed.) (2007), Sourcebook in Late-Scholastic Monetary Theory: The Contributions of Martin de Azpilcueta, Luis de Molina, S. J., and Juan de Mariana, S. J., Lanham: Lexington Books.

Grice-Hutchinson, Marjorie (1952), The School of Salamanca: Readings in Spanish Monetary Theory, 1544-1605, Oxford: Clarendon Press.

Grice-Hutchinson, Marjorie (1978), Early Economic Thought in Spain, 11771740, London: Allen \& Unwin.

Grice-Hutchinson, Marjorie (1989), 'El concepto de Escuela de Salamanca: sus orígenes y desarrollo', Revista de Historia Económica, VII(2), 21-26.

Grice-Hutchinson, Marjorie (1993), Economic Thought in Spain: Selected Essays of Marjorie Grice-Hutchinson, Aldershot: Edward Elgar.

Hamilton, Earl J. (1934) American Treasure and the Price Revolution in Spain, 1501-1650, New York: Octagon Books.

Hernández, Ramón (1977), Un español en la ONU, Francisco de Vitoria, Madrid: Biblioteca de Autores Cristianos.

Hernández, Ramón (1995), Francisco de Vitoria. Vida y pensamiento internacionalista, Madrid: Biblioteca de Autores Cristianos.

Iparraguirre, Demetrio (1957), Francisco de Vitoria: una teoría social del valor económico, Bilbao: Universidad de Deusto. 
Cendejas Bueno José Luis (2021), Justice and just price in Francisco

de Vitoria's Commentary on Summa Theologica II-II q77,

The Journal of Philosophical Economics: Reflections on Economic and Social Issues,

XIV (1-2), 1-32

Langholm, Odd (1979), Price and Value in the Aristotelian Tradition. A Study in Scholastic Economic Sources, Oslo: Universitetsforlaget.

Langholm, Odd (1998a), The Legacy of Scholasticism in Economic Thought: Antecedents of Choice and Power, Cambridge: Cambridge University Press.

Langholm, Odd (1998b), 'The Medieval Schoolmen (1200-1400).' In Ancient and Medieval Economic Ideas and Concepts of Social Justice, edited by S. Todd Lowry, and Barry Gordon, Leiden: Brill.

Larraz, José (1943, 1963), La época del mercantilismo en Castilla, 1500-1700. Real Academia de Ciencias Morales y Políticas, Madrid: Aguilar.

Lowry, S. Todd, and Barry Gordon (ed.) (1998), Ancient and Medieval Economic Ideas and Concepts of Social Justice, Leiden: Brill.

Mercado, Tomás de ([1571] 1975, 1977), Suma de tratos y contratos. Edited by Restituto Sierra Bravo. Madrid: Editora Nacional, also edited by Nicolás Sánchez Albornoz, Madrid: Instituto de Estudios Fiscales.

Molina, Luis de ([1597] 1981, 2011), La teoría del justo precio, edited by Francisco Gómez Camacho, Madrid: Editora Nacional. 2nd edition, Valladolid: Maxtor.

Monsalve, Fabio (2010), 'Economics and ethics: Juan de Lugo's theory of the just price, or the responsibility of living in society', History of Political Economy 42(3), 495-519.

Munro, John H. (2008), 'Price Revolution.' In The New Palgrave Dictionary of Economics, edited by Steven N. Durlauf, and Lawrence E. Blume, vol. 6, London: Macmillan.

Muñoz, Rodrigo (1998), Moral y economía en la obra de Martín de Azpilcueta, Pamplona: Eunsa.

Pena, Miguel A. (2009), La Escuela de Salamanca, de la Monarquía hispánica al Orbe católico, Madrid: Biblioteca de Autores Cristianos.

Perdices, Luis (ed.) (2008), Historia del pensamiento económico, Madrid: Síntesis. 
Cendejas Bueno, José Luis (2021), Justice and just price in Francisco

de Vitoria's Commentary on Summa Theologica II-II q77,

The Journal of Philosophical Economics: Reflections on Economic and Social Issues,

XIV (1-2), 1-32

Pereña, Luciano (ed.) (1984), Francisco de Vitoria y la Escuela de Salamanca. La ética en la conquista de América, Corpus Hispanorum de Pace, vol. XXV, Madrid: CSIC.

Pereña, Luciano (1986), La Escuela de Salamanca. Proceso a la conquista de América, Salamanca: Caja de Ahorros y Monte de Piedad de Salamanca.

Pereña, Luciano (1992), La idea de justicia en la conquista de América, Madrid: Mapfre.

Popescu, Oreste (1997), Studies in the History of Latin American Economic Thought, London: Routledge.

Roover, Raymond de (1955), 'Scholastic economics: survival and lasting influence from the sixteenth century to Adam Smith', Quarterly Journal of Economics, 69(2), 161-190.

Roover, Raymond de (1958), 'The Concept of the Just Price: Theory and Economic Policy', Journal of Economic History, 18(4), 418-434.

Roover, Raymond de (1967), San Bernardino of Siena and sant'Antonino of Florence: the two great economic thinkers of the Middle Ages, Boston, Mass.: Harvard University.

Rothbard, Murray N. (1995), Economic Thought before Adam Smith: An Austrian Perspective on the History of Economic Thought, Cheltenham, UK: Edward Elgar.

Sayous, André E. (1928), 'Observations d'écrivains du xviiéme siécle sur les changes', Revue Economique Internationale, 4, 291-320.

Schumpeter, Joseph A. (1954), History of Economic Analysis, London: Routledge.

Sierra, Restituto (1975), El pensamiento social y económico de la Escolástica desde sus orígenes al comienzo del Catolicismo social, Madrid: CSIC, Instituto de Sociología Balmes.

Soria y Vera, Melchor de ([1627] 1992), Tratado de la justificación y conveniencia de la tassa del pan, edited by Francisco Gómez Camacho, Madrid: Fundación Banco Exterior. 
Cendejas Bueno José Luis (2021), Justice and just price in Francisco

de Vitoria's Commentary on Summa Theologica II-II q77,

The Journal of Philosophical Economics: Reflections on Economic and Social Issues,

XIV (1-2), 1-32

Tedde, Pedro, and Luis Perdices (1999), 'La Escuela de Salamanca en el siglo XVI español', in Economía y Economistas Españoles, edited by Enrique Fuentes, Barcelona: Galaxia Gutenberg.

Vigo, Abelardo del (1981), 'Las tasas y las pragmáticas reales en los moralistas españoles del Siglo de Oro', Burgense: Collectanea Scientifica, 22(2), 427-470.

Vigo, Abelardo del (1997), Cambistas, mercaderes y banqueros en el Siglo de Oro español, Madrid: Biblioteca de Autores Cristianos.

Vigo, Abelardo del (2006), Economía y ética en el siglo XVI, Madrid: Biblioteca de Autores Cristianos.

Vitoria, Francisco de (1932, 1934, 1935, 1952), Comentarios a la Secunda Secundae de Santo Tomás, edited by Vicente Beltrán de Heredia in five volumes, Salamanca: Biblioteca de Teólogos Españoles.

Vitoria, Francisco de (1991), Political writings. Edited by Anthony Pagden, and Jeremy Lawrance, Cambridge: Cambridge University Press.

Vitoria, Francisco de ([1535] 2001), La justicia: qq 57-61, edited by Luis Frayle, Madrid: Tecnos.

Vitoria, Francisco de (2006), Contratos y usura, edited by Idoya Zorroza, Pamplona: Eunsa.

Vitoria, Francisco de (2017), Relecciones jurídicas y teológicas, edited by Antonio Osuna et al., Salamanca: San Esteban.

José Luis Cendejas Bueno is researcher at the Universidad Francisco de Vitoria, Madrid (Spain) (jl.cendejas@ufv.es). 